\title{
Assessing employability capacities and career adaptability in a sample of human resource professionals
}

\begin{tabular}{|c|c|}
\hline \multicolumn{2}{|c|}{$\begin{array}{l}\text { Authors: } \\
\text { Melinde Coetzee }^{1} \\
\text { Nadia Ferreira }{ }^{2} \\
\text { Ingrid L. Potgieter }\end{array}$} \\
\hline $\begin{array}{l}\text { Affiliations: } \\
{ }^{1} \text { Department } \\
\text { and Organisat } \\
\text { Psychology, U } \\
\text { South Africa, }\end{array}$ & $\begin{array}{l}\text { f Industrial } \\
\text { ional } \\
\text { niversity of } \\
\text { south Africa }\end{array}$ \\
\hline $\begin{array}{l}{ }^{2} \text { Department } \\
\text { Resource Man } \\
\text { University of } \\
\text { South Africa }\end{array}$ & $\begin{array}{l}\text { fogement, } \\
\text { louth Africa, }\end{array}$ \\
\hline $\begin{array}{l}\text { Corresponden } \\
\text { Melinde Coet }\end{array}$ & zee to: \\
\hline $\begin{array}{l}\text { Email: } \\
\text { coetzm1@uni }\end{array}$ & sa.ac.za \\
\hline $\begin{array}{l}\text { Postal addres } \\
\text { PO Box 392, P } \\
\text { South Africa }\end{array}$ & retoria 0003 , \\
\hline $\begin{array}{l}\text { Dates: } \\
\text { Received: } 15 \mathrm{~J} \\
\text { Accepted: } 14 \\
\text { Published: } 04\end{array}$ & $\begin{array}{l}\text { an. } 2015 \\
\text { Apr. } 2015 \\
\text { June } 2015\end{array}$ \\
\hline $\begin{array}{l}\text { How to cite th } \\
\text { Coetzee, M., F } \\
\text { \& Potgieter, I.L } \\
\text { Assessing emp } \\
\text { capacities and } \\
\text { adaptability in } \\
\text { of human reso } \\
\text { professionals. } \\
\text { of Human Res } \\
\text { Management/ } \\
\text { Menslikehulph } \\
\text { 13(1), Art. \#68 } \\
\text { http://dx.doi. } \\
\text { sajhrm.v13i1. }\end{array}$ & $\begin{array}{l}\text { is article: } \\
\text { erreira, N., } \\
\text { ( }(2015) \text {. } \\
\text { loyability } \\
\text { career } \\
\text { a sample } \\
\text { urce } \\
\text { SA Journal } \\
\text { ource } \\
\text { SA Tydskrif vir } \\
\text { ronbestuur, } \\
32,9 \text { pages. } \\
\text { rg/10.4102/ } \\
582\end{array}$ \\
\hline $\begin{array}{l}\text { Copyright: } \\
\text { (C) 2015. The A } \\
\text { Licensee: AOS } \\
\text { OpenJournals. } \\
\text { licensed unde } \\
\text { Commons Attr } \\
\text { License. }\end{array}$ & $\begin{array}{l}\text { IS } \\
\text { IS } \\
\text { This work is } \\
r \text { the Creative } \\
\text { ibution }\end{array}$ \\
\hline $\begin{array}{l}\text { Read online: } \\
\text { 口. }\end{array}$ & $\begin{array}{l}\text { Scan this QR } \\
\text { code with your } \\
\text { smart phone or } \\
\text { mobile device } \\
\text { to read online. }\end{array}$ \\
\hline
\end{tabular}

Authors:

Melinde Coetzee

Nadia Ferreira ${ }^{2}$

Ingrid L. Potgieter

and Organisational

Psychology, University of

Department of Human University of South Africa,

Correspondence to:

Email:

Postal address:

PO Box 392, Pretoria 0003

Received: 15 Jan 2015

Accepted: 14 Apr. 2015

How to cite this article: Coetzee, M., Ferreira, N Potgieter, I.L. (2015). of Human Resource Management/SA Tydskrif vir http://dx.doi.org/10.4102/ sajhrm.v13i1.682 Licensee: AOSIS licensed under the Creative Commons Attribution License.

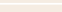

to read online.
Orientation: Employers have come to recognise graduates' employability capacities and their ability to adapt to new work demands as important human capital resources for sustaining a competitive business advantage.

Research purpose: The study sought (1) to ascertain whether a significant relationship exists between a set of graduate employability capacities and a set of career adaptability capacities and (2) to identify the variables that contributed the most to this relationship.

Motivation for the study: Global competitive markets and technological advances are increasingly driving the demand for graduate knowledge and skills in a wide variety of jobs. Contemporary career theory further emphasises career adaptability across the lifespan as a critical skill for career management agency. Despite the apparent importance attached to employees' employability and career adaptability, there seems to be a general lack of research investigating the association between these constructs.

Research approach, design and method: A cross-sectional, quantitative research design approach was followed. Descriptive statistics, Pearson product-moment correlations and canonical correlation analysis were performed to achieve the objective of the study. The participants $(N=196)$ were employed in professional positions in the human resource field and were predominantly early career black people and women.

Main findings: The results indicated positive multivariate relationships between the variables and showed that lifelong learning capacities and problem solving, decision-making and interactive skills contributed the most to explaining the participants' career confidence, career curiosity and career control.

Practical/managerial implications: The study suggests that developing professional graduates' employability capacities may strengthen their career adaptability. These capacities were shown to explain graduates' active engagement in career management strategies deemed important for their sustained employability in the contemporary career environment.

Contributions: The results of the study offered empirical evidence in support of theoretical views on the self-regulatory capacities underpinning individuals' career adaptability and how these are influenced by their employability capacities.

\section{Introduction}

\section{Focus of the study}

As a mechanism of social integration, employment offers individuals a strategy for participating in and sustaining themselves in society (Savickas, 2005). The societal structures in which the career is pursued are influenced by environmental factors that impact on the employability and career development of individuals (Hall, 2013; Savickas, 2013). Global competitive markets and technological advances are increasingly driving the demand for graduate knowledge and skills in a wide variety of jobs (Nel \& Neale-Shutte, 2013; Tran, 2013; Wickramasinghe \& Perera, 2010). Employers have come to recognise graduates' employability capacities and their ability to adapt to new work demands as important human capital resources for sustaining a competitive business advantage (Kyllonen, 2013; Sung, Ng, Loke \& Ramos, 2013). Employability capacities refer to sets of portable 'soft' skills and attributes (such as, for example, people-related and teamrelated skills, conceptual thinking and problem solving skills, goal setting and management skills, knowledge of the business world and skills related to innovation and change and the profession and community) that are important in determining graduates' work readiness and success in the workplace (Coetzee, 2014a; Daniels \& Brooker, 2014; Kyllonen, 2013; Rocha, 2012; Sung et al., 2013; Tran, 2013). As enabling human capital resources, these capacities support 
the career development and employability of graduates through lifelong learning endeavours (Rocha, 2012). Welldeveloped employability capacities help individuals to function successfully within a continuously evolving work environment and to contribute to business-crucial employer requirements over the course of their working lives (Daniels \& Brooker, 2014; Tomlinson, 2010).

\section{Background to the study}

Individuals' employability has been associated with their agency in proactively managing their careers beyond those offered by the organisation (Hall, 2013; Hess, Jepsen \& Dries, 2012; McArdle, Waters, Briscoe \& Hall, 2007; Sullivan, 2013). Contemporary career theory therefore emphasises career adaptability across the lifespan as a critical skill for career management agency (Del Corso, 2013; Hess et al., 2012). Career adaptability refers to the self-regulatory psychosocial resources individuals need to successfully manage current and anticipated career transitions and adjustments (Savickas, 2013). Notions of graduate level employment positions and linear, upward career paths are no longer realistic expectations for graduates in the 21st century work environment (Wickramasinghe \& Perera, 2010). Career paths and patterns have become unpredictable and more blurred with the advent of globalisation and the mobilisation of workers across boundaries, organisations and enterprises (Hall, 2013; Hess et al., 2012). In order to sustain their employability, individuals must have the capacity not only to adapt within their respective occupations to keep up with advances in technology but also to adapt between occupations and different life roles at a rate that is unprecedented compared to previous generations (Del Corso, 2013). The career is no longer seen as a lifetime commitment to one employer, but as a recurrent selling of innovative services and updated skills to a series of employers who need projects completed (Savickas, 2012). Individuals must be flexible, proactive, embrace lifelong learning, seek out new skills and think globally in order to keep up with the pace of change and comply with the requirements of employers (Del Corso, 2013).

\section{Research purpose}

In the current article, we were interested in exploring the relationship between graduate employees' employability capacities and their career adaptability. Both these constructs relate to self-regulatory capacities considered important for contemporary career management (De Guzman \& Choi, 2013; Savickas, 2013; Van der Heijde, 2014). Despite the apparent importance attached to employees' employability and career adaptability, there appears to be a general lack of research investigating the association between these constructs, especially in the South African workplace context. Research by De Guzman and Choi (2013) amongst technical secondary school students showed important associations between employability skills such as communication, problem solving and teamwork skills and career adaptability. The present study extends De Guzman and Choi's research by focusing on the employed professional graduate and by investigating a wide range of employability capacities recognised as being important for graduates' employability. Specifically, by employing canonical correlation analysis, we sought (1) to ascertain whether a significant relationship exists between a set of employability capacities and a set of career adaptability capacities and (2) to identify the variables that contributed the most to this relationship.

\section{Literature review Employability capacities}

Employability refers to the ability to gain and maintain employment and to manage employment transitions such as transitions between organisations and transitions between jobs and roles within the same organisation to meet changing job requirements (Hillage \& Pollard, 1999; Wickramasinghe \& Perera, 2010). Employees are seen to be employable if they have up-to-date technical knowledge about their working domain, demonstrate openness and resilience towards contextual and workplace changes (Froehlich, Beausaert, Segers \& Gerken, 2014) and if they are able to demonstrate a range of transferable generic capacities (Rocha, 2012). Research scholars highlight problem solving and decision-making, critical thinking, writing and speaking (communication skills), proficiency in English, teamwork, interpersonal skills, research skills, information literacy and ethical awareness as important generic graduate employability capacities (cf. Dhiman, 2012; Faber, López \& Prescher 2012; Griesel \& Parker, 2009; McNeil et al., 2012; Spencer, Riddle \& Knewstubb, 2012; Steur, Jansen \& Hofman, 2012; Velasco, 2012). The transformative nature of graduate employability capacities assists in cultivating three overarching attitudinal stances of personal and intellectual development: scholarship, global and moral citizenship and lifelong learning (Barrie, 2004; Coetzee \& Schreuder, 2011; Steur et al., 2012).

Scholarship represents graduates' attitude or stance towards the production and application of new knowledge in order to conscientiously solve complex problems within organisations and society (Barrie, 2004; Steur et al., 2012). Problem solving and decision-making skills, analytical thinking skills and enterprising skills generally contribute to graduates' scholarship (Barrie, 2004; Coetzee, 2014a). Employers regard the development of graduates' scholarship attributes (i.e. their problem solving, information and decision management and lateral thinking and creativity capabilities) as vital for graduate employability (Jackson \& Chapman, 2011).

Global and moral citizenship refers to graduates' attitude or stance towards the world and their communities. It generally includes the ability to function effectively, efficiently and responsibly as a person in communicating and interacting with people from diverse cultures, backgrounds and authority levels, both globally and locally (Coetzee, 2014b). Ethical and responsible behaviour, presenting and applying information skills and interactive skills contribute to graduates' global and moral citizenship (Coetzee, 2014a). 
Lifelong learning relates to graduates' attitude or stance towards themselves and includes goal-directed behaviour and a continuous learning orientation (Barrie, 2004; Coetzee, 2014a). Goal-directed behaviour is an important aspect of individuals' self-managed employability (Bezuidenhout, 2011). A continuous learning orientation denotes a cognitive meta-awareness and openness towards one's own learning, a willingness to proactively engage in the process of acquiring new knowledge, skills and abilities throughout one's life and career in reaction to, and in anticipation of, changing technology and business performance criteria (Coetzee, 2014a). Employability and continuous learning concerns have become an integral aspect of career success in the 21st century career environment (Hall, 2013). Research by Coetzee (2014b) shows that scholarship capacities increase self-directed behaviour whilst global and moral citizenship attributes seem to enhance sense of agency and motivation. Graduates' employability skills and attributes were also shown to be positively associated with their optimism about future career prospects (Coetzee, 2012).

\section{Career adaptability}

Career adaptability denotes a set of transactional resources comprising certain attitudes, competencies and behaviours that enable job search opportunities and facilitate the creation of alternative career improvement options, fitting oneself to preferred work contexts and participating positively in the work role (Duffy, 2010; Klehe, Zikic, Van Vianen, Koen \& Buyken, 2012; Savickas, 1997, 2013; Tolentino et al., 2013). The self-regulatory strengths underpinning individuals' career adaptability are seen to prepare them to cope with current and anticipated occupational changes and transitions and adjustments due to unpredictable changes in work and working conditions (Duffy, 2010; Savickas \& Porfeli, 2012; Tolentino et al., 2013).

Career adaptability has been described along four different dimensions or syndromes, which include concern ('Do I have a future?': showing concern for one's future, being engaged in planning by being aware, involved and prepared), control ('Who owns my future?': degree to which an individual engages and exerts control over their future through decision-making, determination and agency), curiosity ('What do I want to do with my future?': how individuals gather occupational information and self-knowledge as they attempt to fit themselves into the world of work) and confidence ('Can I do it?': the degree to which individuals feel a sense of self-efficacy to overcome obstacles as they work to implement their career goals) (Del Corso, 2013; Savickas, 2005, 2013; Savickas \& Porfeli, 2012). The four domains of career adaptability are seen to relate to important vocational developmental tasks, which entail a primary adaptive goal that, when accomplished, builds a foundation for career success, future adaptability and growth (Hartung, 2013).

Career concern involves a future orientation, feeling optimistic about it and demonstrating a planful attitude about the future (Hartung, 2013). Being concerned about one's future requires one to be aware, involved and preparatory (Savickas, 2005, 2013). Career control involves a sense of self-direction and self-regulation prompted by taking responsibility for one's future and the career decisionmaking tasks it involves (Hartung, 2013). Problems with career control can manifest as career indecision. Individuals with low sense of career control may tend to struggle with uncertainty and indecisiveness in today's work environment. Demonstrating personal control over one's career enables individual to better embrace uncertainty and concomitant anxieties (Del Corso, 2013).

Career curiosity leads to productive career exploration stemming from an inquisitive attitude toward the career (Hartung, 2013). Adapting to changing contexts or situations, individuals must display an inquisitive attitude and engage in exploration by experimenting, taking risks and inquiring (Savickas, 2005, 2013). Career confidence is reflected in demonstrating an efficacious attitude in solving problems and effectively navigating obstacles to constructing the future (Hartung, 2013). Career inhibition (contrary to career confidence) occurs when individuals feel they are unable to work through occupational difficulties (Savickas, 2005, 2013). Career confidence is demonstrated in how individuals deal with the myriad stressors they may encounter throughout their lifetime along the career journey, for example sudden unemployment, lack of available jobs, health problems, family struggles, unexpected workplace challenges or pressure to learn new skills (Del Corso, 2013).

Both graduate employability capacities and career adaptability are important self-regulatory psychosocial resources for individuals' continuous learning and employability (Bezuidenhout, 2011). In the present article, we assumed that the transferable skills and attributes reflected in the graduate employability capacities may help to strengthen individuals' career adaptability. High levels of career adaptability are positively associated with future job search self-efficacy, employment status, perceptions of the future work self, person-environment fit (Guan et al., 2014) and career satisfaction (Zacher, 2014).

\section{What will follow}

The next section elaborates on the research design for this study, including the research approach and method. The results are then presented and the findings discussed. The article concludes with a brief outline of the most important conclusions and implications for management. Finally, the limitations of the research design are outlined and recommendations for possible future research initiatives are formulated.

\section{Research design Research approach}

A cross-sectional, quantitative research approach was followed to collect primary data. 


\section{Method \\ Participants}

A purposive non-probability sample $(N=196)$ of employed adults participated in the study. The participants were enrolled for further studies in the human resource management field at a distance learning higher education institution. They were employed in professional positions in the human resource field and comprised predominantly $88 \%$ black people and $73 \%$ women in the early career stage $(80 \%<45$ years).

\section{Measuring instruments}

Graduate employability capacities were measured by means of the graduate skills and attributes scale (GSAS) developed by Coetzee (2014a). The GSAS is a multifactorial self-rating scale consisting of 64 items and eight subscales: problem solving and decision-making skills (eight items, e.g. 'I consider the complexities of the larger cultural, business, and economic reality when approaching a problem or situation'), enterprising skills (nine items, e.g. 'I find it easy to identify business opportunities for myself, my community or organisation'), analytical thinking skills (four items, e.g. 'I can make a rational judgment from analysing information and data'), interactive skills (16 items, e.g. 'I find it easy to communicate effectively with people from different cultures, backgrounds and authority levels'), presenting and applying information skills (five items, e.g. 'The solutions I offer make a positive difference in my personal life, community or workplace'); ethical and responsible behaviour (five items, e.g. 'I uphold the ethics and values of my profession, community or workplace in all I do'), goal-directed behaviour (10 items, e.g. 'I develop plans for specific goals and tasks') and continuous learning orientation (seven items, e.g. 'I make sure that I keep myself up to date on technical knowledge and new developments in my field'). A six-point Likert-type scale ( $1=$ never true for me; 6 = always true for me) is used for subjects' responses to each of the 64 items. Exploratory and confirmatory factor analysis by Coetzee (2014a) confirmed the construct and structural validity and internal consistency reliability of the GSAS in the South African context. In terms of the present sample, the overall scale obtained a reliability coefficient of 0.97. The internal consistency reliability coefficients for the eight subscales ranged between 0.76 (ethical and responsible behaviour) and 0.91 (interactive skills).

Career adaptability was measured by means of the career adapt-abilities scale (CAAS). The CAAS (Savickas \& Porfeli, 2012) is a multifactorial self-rating measure, consisting of 24 items and four subscales: concern (six items, for example 'Thinking about what my future will be like'), control (six items, for example 'Taking responsibility for actions'), curiosity (six items, for example 'Becoming curious about new opportunities') and confidence (six items, for example 'Performing tasks efficiently'). A five-point Likert-type scale ( 1 = not strong; 5 = strongest $)$ is used for subjects' responses to each of the 24 items. Confirmatory factor analysis by Maree (2012) confirmed the construct and structural validity and internal consistency reliability of the CAAS in the South
African context. In terms of the present sample, the overall scale obtained a reliability coefficient of 0.94 . The following Cronbach's alpha coefficients (internal consistency) for the four subscales were obtained: career concern (0.75), career control (0.72), career curiosity (0.79) and career confidence (0.80).

\section{Procedure and ethical considerations}

The survey was conducted during a school study programme that was attended by the participants. The participants were invited to voluntarily participate and signed an informed consent form. The privacy, anonymity and confidentiality of all the participants were ensured and honoured (e.g. the research responses were anonymous and only used for research purposes by the researchers). Ethical clearance and permission to conduct the research were obtained from the management of the university.

\section{Statistical analysis}

Descriptive statistics (means, standard deviations and Cronbach's alpha coefficients), Pearson's product-moment correlations (using SPSS) and canonical correlation analysis (using SAS) were performed. The practical significance (Cohen, 1992) for interpreting the Pearson's correlations $(r)$ was as follows: $r$ less than 0.10 for a small practical effect, $r$ less than 0.30 for a moderate practical effect and $r$ greater than 0.50 for a large practical effect. Multicollinearity concerns were set at $r$ greater than 0.90 (Hair, Black, Babin \& Anderson, 2010). The relative importance of the canonical loadings was assessed by applying the cut-off criteria for canonical factorial loadings $(\geq 0.30)$. The magnitude of the overall correlational relationships between the two variates of a canonical function and the practical significance of the predictive ability of the canonical relationship were determined by considering the $r^{2}$ type effect size $(1-0 . \lambda$; Hair et al., 2010). The practical significance for interpreting the $r^{2}$ type effect size was in line with the guidelines of Cohen (1992): $r^{2}$ less than 0.01 for a small practical effect, $r^{2}$ less than 0.09 for a moderate practical effect and $r^{2}$ greater than 0.25 for a large practical effect. The graduate attributes were treated as the set of independent variables and the career adaptability variables as the set of dependent variables. The participants' age, gender and race were used as controls to explore the relationships between the research variables.

\section{Results \\ Descriptive statistics and correlations}

The reliability coefficients reported in Table 1 show acceptable internal consistency reliability of the two scales and the subscales. The overall scale reliability coefficient of the graduate skills and attributes scale was very high $(\alpha=$ $0.97)$ as well as the reliability coefficient of the overall career adaptability scale $(\alpha=0.94)$. These coefficients indicated strong overall internal consistency for the two scales.

As can be seen from Table 1, the practical effect of the significant inter-correlations amongst the GSAS and CAAS 


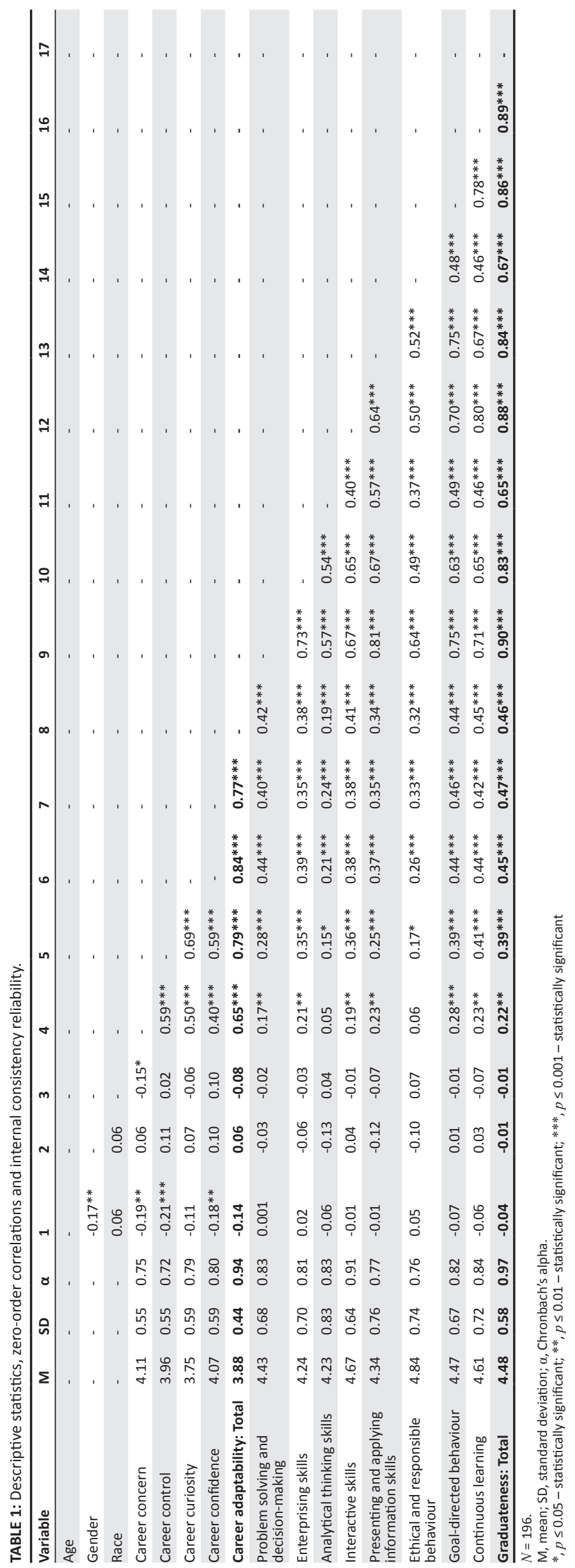


TABLE 2: Results of the standardised canonical correlation analysis for the first canonical function.

\begin{tabular}{|c|c|c|c|c|c|}
\hline Variate & Variables & Canonical coefficients & $\begin{array}{l}\text { Structure } \\
\text { coefficient }(R c)\end{array}$ & $\begin{array}{l}\text { Canonical } \\
\text { cross-loadings }(R c)\end{array}$ & $\begin{array}{l}\text { Squared canonical } \\
\text { loadings }\left(R c^{2}\right)\end{array}$ \\
\hline \multirow{8}{*}{$\begin{array}{l}\text { Graduate attributes canonical variate } \\
\text { variables }\end{array}$} & Problem solving and decision-making skills & 0.24 & 0.83 & 0.44 & 0.20 \\
\hline & Enterprising skills & 0.21 & 0.74 & 0.40 & 0.16 \\
\hline & Analytical thinking skills & -0.10 & 0.43 & 0.23 & 0.05 \\
\hline & Interactive skills & 0.07 & 0.82 & 0.44 & 0.19 \\
\hline & Presenting and applying information skills & -0.38 & 0.64 & 0.34 & 0.12 \\
\hline & Ethical and responsible behaviour & 0.19 & 0.65 & 0.35 & 0.12 \\
\hline & Goal-directed behaviour & 0.57 & 0.90 & 0.48 & 0.23 \\
\hline & Continuous learning orientation & 0.26 & 0.90 & 0.48 & 0.23 \\
\hline \multirow{4}{*}{$\begin{array}{l}\text { Career adaptability canonical variate } \\
\text { variables }\end{array}$} & Career concern & -0.18 & 0.43 & 0.23 & 0.05 \\
\hline & Career control & 0.41 & 0.83 & 0.44 & 0.20 \\
\hline & Career curiosity & 0.29 & 0.83 & 0.45 & 0.19 \\
\hline & Career confidence & 0.56 & 0.90 & 0.49 & 0.24 \\
\hline
\end{tabular}

Overall model fit measures (function 1$)$ :

Overall $R c^{2}=0.29 ; \mathrm{F}(p)=2.65(p<0.0001) ; d f=32 ; 514.20$; Overall proportion: 0.63 ; Wilks's lambda $(\lambda)=0.569 * * * ; r^{2}$ type effect size: $1-0 . \lambda=0.431$ (large practical effect).

Redundancy index (standardised variance of career adaptability explained by graduate attributes):

Proportion $=0.17 ; N=196$

subscale variables respectively ranged between 0.40 and 0.80 (moderate to large effect; $p \leq 0.001$ ). With the exception of the analytical thinking skills $(r=0.65)$ and the ethical responsible behaviour $(r=0.67)$ subscales, the GSAS subscales had high correlations with the overall GSAS scale $(r \geq 0.83 \leq 0.90)$. The CAAS subscales also correlated strongly with the overall CAAS scale $(r \geq 0.65 \leq 0.84)$. Because of the strong zeroorder correlations between the subscales and the respective overall scale, the two overall scales were not included in the canonical correlation analysis in order to address concerns of possible multicollinearity.

The significant inter-correlations between the GSAS and CAAS variables were small to moderate in practical effect $(r \geq$ $0.15 \leq 0.47 ; p \leq 0.05$ ), suggesting that multicollinearity did not pose a threat to the interpretation of the canonical correlation results. The associations between age, gender and race and the GSAS and CAAS variables were small in practical effect and regarded as negligible.

\section{Canonical correlations}

Canonical correlation analysis was used to study the multivariate relationships between the eight GSAS scores (problem solving and decision making skills, enterprising skills, analytical thinking skills, interactive skills, presenting and applying information skills, ethical and responsible behaviour, goal-directed behaviour and continuous learning orientation) and the four CAAS scores (career concern, career control, career curiosity and career confidence). The GSAS variables were treated as the set of independent variables and the CAAS variables as the set of dependent variables.

Table 2 shows that the full model was significant using Wilks's multivariate test criterion (Wilks's lambda, $\lambda,=0.569$, function 1: $\mathrm{F} p=2.65 ; p=0.0001)$. Only the first function of the model was significant and contributed $29 \%\left(R \mathrm{c}^{2}=0.29\right)$ of the overall explained variation relative to the function. The full model $r^{2}$ type effect size (yielded by $1-0 . \lambda$ ) was 0.43 (large practical effect), indicating that the full model explains an adequate proportion, about $43 \%$ of the variance shared between the two variable sets. The redundancy index results summarised in Table 2 show that the employability capacities explained $17 \%\left(R c^{2}=17\right.$; moderate practical effect $)$ of the variance in career adaptability and was able to predict $63 \%$ (large practical effect) of the proportion of variance in the individual original career adaptability variables.

Table 2 provides the canonical coefficients (weights), canonical structure coefficients $(R c)$, canonical cross-loadings $(R c)$ and squared canonical loadings $\left(R c^{2}\right)$. The four CAAS variables all loaded positively with the career adaptability canonical construct and were assumed to represent high career adaptability. Career concern $(R c=0.43)$ showed the lowest loading in comparison with career control $(R c=0.83)$, career curiosity $(R c=0.83)$ and career confidence $(R c=0.90)$.

Goal-directed behaviour $(R c=0.90)$ and continuous learning $(R c=0.90)$ showed the highest loading with the employability capacities canonical construct as measured by the GSAS, followed by problem solving and decision-making skills $(R c=0.83)$ and interactive skills $(R c=0.82)$.

Using 0.40 as the cut-off value for interpreting the results, Table 2 further shows that the employability capacities contributed positively in explaining the variance in three of the original career adaptability variables: career confidence $(R c=0.49 ; 24 \%)$, career curiosity $(R c=0.45 ; 20 \%)$ and career control $(R c=0.44 ; 19 \%)$. The career adaptability variables contributed positively in explaining the variance in especially goal-directed behaviour $(R c=0.48 ; 23 \%)$, continuous learning orientation $(R c=0.48 ; 23 \%)$, problem solving and decisionmaking skills $(R c=0.44 ; 19 \%)$, interactive skills $(R c=0.44$; $19 \%)$ and enterprising skills $(R c=0.40 ; 16 \%)$.

\section{Discussion}

In this study we sought (1) to ascertain whether a significant relationship exists between a set of employability capacities and a set of career adaptability capacities and (2) to identify the variables that contributed the most to this relationship. Overall, the results showed positive associations between the 
employability capacities and career adaptability constructs. The lack of association between the biographical variables of age, gender and race and the participants' employability capacities and career adaptability could be attributed to the relatively small sample size.

In line with research by De Guzman and Choi (2013), we expected positive associations between the two sets of constructs and that the problem solving and decisionmaking skills, interactive (team) skills and presenting and applying information (communication) skills would be strong predictors of career adaptability. Our results showed that participants with high levels of problem solving and decision-making and interactive skills were also likely to be actively engaged in career management strategies relating to career control (taking responsibility for career decision-making and goal implementation), career curiosity (gathering occupational information) and career confidence (being confident about their ability to implement career goals and solve problems). These findings contributed empirical evidence in support of the view that career adaptability seems dependent upon individuals' problem solving strategies and decision-making abilities (Del Corso \& Rehfuss, 2011).

Although our results confirmed the importance of problem solving and decision-making and interactive skills in predicting individuals' level of career adaptability, our study revealed goal-directed behaviour and continuous learning as the strongest predictors of career adaptability. The findings showed that the lifelong learning capacities (goaldirected behaviour and continuous learning orientation) contributed the most to explaining higher levels of career confidence, career curiosity and career control. These three career adaptability capacities represent a sense of agency and responsibility (control), motivation and willingness (curiosity) and efficacy (confidence) to actively engage in vocational developmental tasks that will help individuals adjust proactively to unexpected needs that may arise from changes in the labour market or working conditions (Nota, Ginevra, Santili \& Soresi, 2014; Savickas \& Porfeli, 2012). The findings contributed valuable empirical evidence in support of Hall's (2013) view that lifelong learning has become an important career meta-capacity for sustaining employability in the contemporary career environment. Career adaptability is also seen as an important resource throughout the lifespan for sustaining employability (Savickas, 2011).

\section{Limitations and future research directions}

Several limitations need to be noted in the interpretation of the results. Firstly, canonical correlation analysis is a maximisation technique and in interpreting the results, researchers and practitioners should be aware of the possibility of overestimation due to the amplification of linear composites (Hair et al., 2010). Secondly, the sample was confined to a relatively small group of human resource professionals, which limits the interpretability of the results to populations in different occupations. Testing the variables on various multicultural populations from various occupational groups may further inform theories of career adaptability in the employability context for diverse groups of employees. Thirdly, the self-report nature of the study could have contributed to spuriously strong relationships between the variables as a result of method variance limitation. Finally, the cross-sectional nature of our study limits the nature of data obtained to a specific moment in time. Much would be gained by future longitudinal research analysing the shift in levels of employability capacities and career adaptability as the career self-concept evolves over time.

\section{Practical implications}

The study suggests that developing professional graduates' employability capacities may strengthen their career adaptability. These capacities were shown to positively explain graduates' active engagement in career management strategies deemed important for their sustained employability in the contemporary career environment. More specifically, human resource practitioners and career development practitioners should ensure that graduate professionals continue to be engaged in challenging job assignments that draw on their problem solving, decision-making and teamwork skills as part of their on-the-job career development. Workplace-based career development interventions should consider problem-based learning activities, which have been shown to promote critical thinking and problem solving skills. Such activities should facilitate individual agency in self-directed learning, personal learning needs identification, collaborative teamwork and interaction with and learning from peers, mentors and coaches as a consequence of active participation in the learning process (Gurses, Acikyildiz, Dogar \& Sozbilir, 2007). Our research showed that a lifelong learning orientation and problem solving, decision making and teamwork skills were positively associated with higher levels of career adaptability, including career management strategies relating to taking responsibility for career decision-making and goal implementation, gathering occupational information and being confident about one's ability to implement career goals and solve problems. Career development interventions should generally focus on helping graduate professionals to articulate their employability capacities, including the 'transferable skills' that go beyond one occupation, in order to increase their confidence and selfefficacy in demonstrating their skills and abilities to manage their careers and employability (Del Corso, 2013).

\section{Conclusion}

Notwithstanding the limitations of the research design, the study findings contribute new insights to contemporary career theory. Our study provides empirical evidence in support of theoretical views on the self-regulatory capacities underpinning individuals' career adaptability and employability in the South African workplace context. The multivariate approach in ascertaining the relationship between the two sets of variables helped to identify key employability capacities that explain individuals' level of 
career adaptability. It is trusted that the research will stimulate further research on a topic of contemporary relevance and importance for both individuals and organisations.

\section{Acknowledgements Competing interests}

The authors declare that they have no financial or personal relationships that may have inappropriately influenced them in writing this article.

\section{Authors' contributions}

M.C. (University of South Africa) conducted the literature review and data analysis and wrote up the article. N.F. (University of South Africa) and I.L.P. (University of South Africa) assisted with the data collection and critical review of the manuscript.

\section{References}

Barrie,S.C.(2004). Aresearch-basedapproachtogenericgraduateattributespolicy. Higher Education Research \& Development, 23(3), 261-275. http://dx.doi.org/10.1080/ 0729436042000235391

Bezuidenhout, M. (2011). The development and evaluation of a measure of graduate employability in the context of the new world of work. Unpublished master's dissertation, Department of Human Resource Management, University of Pretoria, Pretoria, South Africa.

Coetzee, M. (2012). Distance learning students' graduateness as predictors of their job satisfaction and optimism about future career prospects. Journal of Social Sciences, 33(3), 305-313.

Coetzee, M. (2014a). Measuring student graduateness: Reliability and construct validity of the Graduate Skills and Attributes Scale. Higher Education Research and Development, 33(5), 887-902. http://dx.doi.org/10.1080/07294360.2014.8 90572

Coetzee, M. (2014b). Graduate attributes in relation to academic selfdirectedness in open distance learning: The mediating role of global/moral citizenship and lifelong learning attributes. Higher Education Research and Development, 33(6), 1085-1098. http://dx.doi.org/10.1080/07294360.2014. 911260

Coetzee, M., \& Schreuder, A.M.G. (2011). The relation between career anchors, emotional intelligence and employability satisfaction among workers in the service industry. Southern African Business Review, 15(3), 76-97.

Cohen, J. (1992). Quantitative methods in psychology: A power primer. Psychological Bulletin, 112(1), 155-159. http://dx.doi.org/10.1037/0033-2909.112.1.155

Daniels, J., \& Brooker, J. (2014). Student identity development in higher education: Implications for graduate attributes and work-readiness. Educational Research 56(1), 65-76. http://dx.doi.org/10.1080/00131881.2013.874157

De Guzman, A.B., \& Choi, K.O. (2012). The relations of employability skills to career adaptability among technical school students. Journal of Vocational Behavior, 82, 199-207. http://dx.doi.org/10.1016/j.jvb.2013.01.009

Del Corso, J. (2013). The theory of career adaptability. In A. di Fabio \& J.G. Maree (Eds.), The psychology of career counseling: New challenges for a new era (pp. 117-130). New York, NY: Nova Science Publishers, Inc

Del Corso, J., \& Rehfuss, M. (2011). The role of narrative in career construction theory. Journal of Vocational Behavior, 79, 334-339. http://dx.doi.org/10.1016/j. jvb.2011.04.003

Dhiman, M.C. (2012). Employers' perceptions about tourism management employability skills. Anatolia - An International Journal of Tourism and Hospitality Research, August, 1-14. http://dx.doi.org/10.1080/13032917.2012.711249

Duffy, R.D. (2010). Sense of control and career adaptability among undergraduate students. Journal of Career Assessment, 18(4), 420-430. http://dx.doi. org/10.1177/1069072710374587

Faber, K., López, V., \& Prescher, T. (2012). 'i-learn': Developing a new approach in higher education for lifelong learning. European Journal of Higher Education August, 1-16. http://dx.doi.org/10.1080/21568235.2012.709382

Froehlich, D.E., Beausaert, S., Segers, M., \& Gerken, M. (2014). Learning to stay employable. Career Development International, 19(5), 508-525. http://dx.doi org/10.1108/CDI-11-2013-0139

Griesel, H., \& Parker, B. (2009). Graduate attributes: A baseline study on South African graduates from the perspective of employers. Pretoria: Higher Education South Africa and South African Qualifications Authority.

Guan, Y., Guo, Y., Bond, M.H., Cai, Z., Zhou, X., Xu, J. et al. (2014). New job market entrants' future work self, career adaptability and job search outcomes: Examining mediating and moderating variables. Journal of Vocational Behavior, 85, 136-145. http://dx.doi.org/10.1016/j.jvb.2014.05.003
Gurses, A., Acikyildiz, M., Dogar, C., \& Sozbilir, M. (2007). An investigation into the effectiveness of problem-based learning in a physical chemistry laboratory course. Research in Science \& Technological Education, 25(1), 99-113. http://dx.doi. Research in Science \& Technological
$\mathrm{org} / 10.1080 / 02635140601053641$

Hair, J., Black, W., Babin, B., \& Anderson, R. (2010). Multivariate data analysis. Englewood Cliffs, NJ: Pearson Education.

Hall, D.T. (2013). Protean careers in the 21st century. In K. Inkson, \& M.L. Savickas (Eds.), Career studies, Vol I: Foundations of career studies (pp. 245-254). London, UK: Sage.

Hartung, P.J. (2013). Career construction counseling. In A. di Fabio \& J.G. Maree (Eds.) The psychology of career counseling: New challenges for a new era (pp. 15-28). New York, NY: Nova Science Publishers, Inc.

Hess, N., Jepsen, D.M., \& Dries, N. (2012). Career and employer change in the age of the 'boundaryless' career. Journal of Vocational Behavior, 81, 280-288. http:// dx.doi.org/10.1016/j.jvb.2011.10.009

Hillage, J., \& Pollard, E. (1999). Employability: Developing a framework for policy analysis. London, UK: Department for Education and Employment.

Jackson, D., \& Chapman, E. (2011). Non-technical skill gaps in Australian business graduates. Education + Training, 54(2/3), 95-113.

Klehe, U.C., Zikic, J., Van Vianen, A.E., Koen, J., \& Buyken, M. (2012). Coping proactively with economic stress: Career adaptability in the face of job insecurity, job loss, unemployment and underemployment. Research in Occupational Stress and WellBeing, 10, 131-176. http://dx.doi.org/10.1108/S1479-3555(2012)0000010008

Kyllonen, P.C. (2013). Soft skills for the workplace. Change: The Magazine of Higher Learning, 45(6), 16-23. http://dx.doi.org/10.1080/00091383.2013.841516

Maree, J.B. (2012). Career Adapt-abilities Scale - South African form: Psychometric properties and construct validity. Journal of Vocational Behavior, 80, 730-733. http://dx.doi.org/10.1016/j.jvb.2012.01.005

McArdle, S., Waters, L., Briscoe, J.P., \& Hall, D.T. (2007). Employability during employment: adaptability, career identity and human and social capital. Journal of Vocational Behavior, 71, 247-264. http://dx.doi.org/10.1016/j.jvb.2007.06.003

McNeil, H.P., Scicluna, H.A., Boyle, P., Grimm, M.C., Gibson, K.A., \& Jones, P.D. (2012) Successful development of generic capabilities in an undergraduate medical education program. Higher Education Research \& Development, 31(4), 525-539. http://dx.doi.org/10.1080/07294360.2011.559194

Nel, H., \& Neale-Shutte, M. (2013). Examining the vevidence: Graduate employability at NMMU. South African Journal of Higher Education, 27(2), 437-453.

Nota, L., Ginevra, M.C., Santili, S., \& Soresi, S. (2014). Contemporary career construction: The role of career adaptability. In M. Coetzee (Ed.), Psycho-social career meta-capacities: Dynamics of contemporary career development (pp. career meta-capacities: Dynamics of contemporary career development (pp. 3-319-00645-1_13

Rocha, M. (2012). Transferable skills representations in a Portuguese college sample: Gender, age, adaptability and vocational development. European Journal of Psychology in Education, 27, 77-90. http://dx.doi.org/10.1007/s10212-011-0067-4

Savickas, M.L. (1997). Adaptability: An integrative construct for life-span, lifespace theory. Career Development Quarterly, 45, 247-259. http://dx.doi. org/10.1002/j.2161-0045.1997.tb00469.x

Savickas, M.L. (2005). The theory and practice of career construction. In R.W. Lent \& S.D. Brown (Eds.), Career development and counseling: Putting theory and research to work (pp. 42-70). Hoboken, NJ: John Wiley \& Sons.

Savickas, M.L. (2011). New questions for vocational psychology: premises, paradigms, and practices. Journal of Career Assessment, 19(3), 251-258. http://dx.doi. org/10.1177/1069072710395532

Savickas, M.L. (2012). Life design: A paradigm for career intervention in the 21st century. Journal of Counseling \& Development, 90, 13-19. http://dx.doi. org/10.1111/j.1556-6676.2012.00002.x

Savickas, M.L. (2013). Career construction theory and practice. In R.W. Lent \& S.D. Brown (Eds.), Career development and counselling: Putting theory and research to work (2nd edn., pp. 147-183). Hoboken, NJ: John Wiley \& Sons.

Savickas, M.L., \& Porfeli, E.J. (2012). Career adapt-abilities scale: construction, reliability, and measurement equivalence across 13 countries. Journal of Vocational Behavior, 80, 661-673. http://dx.doi.org/10.1016/j.jvb.2012.01.011

Spencer, D., Riddle, M., \& Knewstubb, B. (2012). Curriculum mapping to embed graduate capabilities. Higher Education Research and Development, 31(2), 217-231. http://dx.doi.org/10.1080/07294360.2011.554387

Statistical Analysis System (SAS) [Computer software]. (2010). Cary, NC: SAS Institute Inc.

Statistical Package of the Social Sciences (SPSS) [Computer software]. (2013). New York, NY: IBM Corporation.

Steur, J.M., Jansen, E.P.W.A., \& Hofman, W.H.A. (2012). Graduateness: An empirical examination of the formative function of university education. Higher Education 64(6), 861-874. http://dx.doi.org/10.1007/s10734-012-9533-4

Sullivan, S.E. (2013). The changing nature of careers: A review and research agenda. In K. Inkson \& M.L. Savickas (Eds.), Career studies, Vol I: Foundations of career studies (pp. 271-302). London, UK: Sage.

Sung, J., Ng, M.C.M., Loke, F., \& Ramos, C. (2013). The nature of employability skills: empirical evidence from Singapore. International Journal of Training and Development, 17(3), 176-193. http://dx.doi.org/10.1111/ijtd.12008

Tolentino, L.R., Garcia, P.R.J.M., Lu, V.N., Restubog, S.L.D., Bordia, P., \& Tang, R.L. (2013). Validation of the Career Adapt-Abilities Scale and an examination of a model of career adaptation in the Philippine context. Journal of Vocational Behavior, 83, 410-418. http://dx.doi.org/10.1016/j.jvb.2013.06.013 
Tomlinson, M. (2010). Investing in the self: Structure, agency and identity in graduates' employability. Education, Knowledge and Economy, 4(2), 73-88. http://dx.doi.org /10.1080/17496896.2010.499273

Tran, T.T. (2013). Limitation on the development of skills in higher education in Vietnam. Higher Education, 65, 631-644. http://dx.doi.org/10.1007/s10734-012 9567-7

Van der Heijde, C.M. (2014). Employability and self-regulation in contemporary careers. In M. Coetzee (Ed.), Psycho-social career meta-capacities: Dynamics of contemporary career development (pp. 7-18). Dordrecht, The Netherlands: Springer. http://dx.doi.org/10.1007/978-3-319-00645-1_1
Velasco, M.S. (2012). More than just good grades: Candidates' perceptions about the skills and attributes employers seek in new graduates. Journal of Business
Economics and Management, 13(3), 499-517. http://dx.doi.org/10.3846/16111 699.2011.620150

Wickramasinghe, V., \& Perera, L. (2010). Graduates', university lecturers' and employers' perceptions towards employability skills. Education + Training, 52(3), 226-244. http://dx.doi.org/10.1108/00400911011037355

Zacher, H. (2014). Individual difference predictors of change in career adaptability over time. Journal of Vocational Behavior, 84, 188-198. http://dx.doi.org/10.1016/j. jvb.2014.01.001 